\title{
The Roman Catholic Church and the Repugnant Conclusion
}

\author{
David Shaw
}

Received: 3 September 2015 / Accepted: 14 December 2015 /Published online: 15 January 2016

(C) Journal of Bioethical Inquiry Pty Ltd. 2016

Keywords Catholicism $\cdot$ Consequentialism $\cdot$ Religion and medical ethics · Derek Parfit

\section{Introduction}

The Roman Catholic Church has a very conservative stance on several bioethical matters, including reproduction, embryo research, assisted dying, and homosexual relationships. Many Catholics themselves adopt a much more liberal approach to such matters, while still remaining adherents to the faith, and in the increasingly secularized developed world, religion has less influence on citizens' lives than in the past. However, Catholic doctrine still affects the lives of both Catholics and nonCatholics through its influence on lawmaking. This editorial uses the thought experiment of a world ruled according to Catholic doctrine to suggest that the global implementation of such policies would lead to a planet that resembles that of Derek Parfit's (1987) "Repugnant Conclusion," where there are tens of billions of people with lives that are barely worth living.

\section{Shaw $(\bowtie)$}

Institute for Biomedical Ethics, University of Basel,

Bernoullistrasse 28, 4056 Basel, Switzerland

e-mail: david.shaw@unibas.ch

\section{The Roman Catholic Planet}

On Earth-C in the year 2015, there have been no schisms whatsoever in Christianity, and the Reformation and Enlightenment never happened; Islam, Judaism, and other religions have faded into memory due to the constant evangelizing and crusading of the second Holy Roman Empire, which achieved global domination in the Middle Ages. Everyone all over the world is brought up according to the Catholic tradition, and exposure to dangerous philosophical texts is denied except to members of Opus Dei. Children are taught that sex should only take place in marriage, and abortions and contraception are illegal. While homosexuality is not illegal, it is deeply condemned by society (as the Church teaches that homosexual thoughts are "disordered" and gay sex is sinful), and since all life is sanctified, patients can only refuse "extraordinary" medical treatment. (See Box 1 for Catholic sources on these issues.)

These doctrine-derived laws and policies cause suffering for many members of the population of Earth-C. Women cannot access contraception or abortion, meaning that their reproductive autonomy is limited and that there are many more unwanted pregnancies as well as deaths from complications of pregnancy and from childbirth. People who are gay are discriminated against and persecuted. Terminally ill patients cannot access assisted dying services, and refusing treatment is very difficult because withdrawal of care is also regarded as being 
against God's will. The Church banned all research involving embryos decades ago, but unfortunately this means that millions more people have suffered with and died from Parkinson's, Alzheimer's, and other diseases (and they have, of course, suffered for longer in some cases because they are not allowed to access assistance in suicide or euthanasia). Furthermore, the human rights of many of these people (from our perspective on real Earth) are also being violated. Of course, on Earth-C, there is no declaration of human rights, only the Holy Declaration of God's Truth upon which all laws are based. Nonetheless, these global policies contribute to a great deal of suffering and harm.

All the aforementioned policies of the Global Catholic Church on Earth-C are unfortunate and harmful for those they affect, but the consequences of the prohibition on contraception and abortion are even further-reaching. Despite the illegal status of sex outside marriage, pregnancy and birth rates have soared under the Catholic regime, to the extent that the world population is already twenty billion and continuing to rise quickly. (Research in our world has shown that attempts at abstinence reduce neither HIV nor pregnancy rates, and forbidding abortion can only have a similar effect [Underhill, Montgomery, and Operario 2007].) The soaring population has already led to a great deterioration in the quality of life of many people, which is only increased by the widespread prevalence of HIV and other sexually transmitted infections (which is itself due to the prohibition of condoms). These problems are further exacerbated by the accelerated global warming caused by so many more carbon footprints and the consequent extreme weather events. The population is projected to reach fifty billion by the end of the century.

\section{The Repugnant Conclusion}

Horrible as this world might sound, the Repugnant Conclusion is that anyone might think that such a world might actually be a better outcome than the one we actually live in - not because it is Catholic, but because there is potentially a greater overall amount of happiness in such a world. Derek Parfit (1987) famously argued that the logical conclusion of accepting utilitarian arguments is that a world with one hundred billion people with lives that are barely worth living would be a better world than one with ten billion people, each of whom is very happy, because the total amount of happiness in the former would exceed that in the latter. He calls this the Repugnant Conclusion because it is repulsively counterintuitive:

For any possible population of at least 10 billion people, all with a very high quality of life, there must be some much larger imaginary population whose existence, if other things are equal, would be better, even though its members would have lives that are barely worth living. ... As my choice of name suggests, I find this conclusion hard to accept (Parfit 1987, 388).

It is at least strongly plausible that Earth-C would resemble the world of the Repugnant Conclusion. Earth-C is overpopulated; there are shortages of food, water, and housing; sex outside marriage is forbidden; HIV and other STIs run rampant across populations; those who are gay are persecuted; and women cannot access contraception or abortion. Nonetheless, their lives are still worth living. By comparison, Parfit characterizes the lives of those living in the world of the Repugnant Conclusion as follows: "There is nothing bad in each of these lives; but there is little happiness, and little else that is good. The people in $\mathrm{Z}$ [the world of the Repugnant Conclusion] never suffer; but all they have is muzak and potatoes" (Parfit 1986, 148). This actually sounds rather better than life on Earth-C.

Now, Catholics (or at least Catholic doctrines) are not consequentialists; this much is clear. They would have to endorse Earth- $\mathrm{C}$ as a consequence of the implementation of their doctrine, even if it is not "heaven on earth." Nonetheless, those in charge of the Church might want to give some thought to the potential effects of their laws, were they to be enforced all over the world. Pope John Paul II (1995) described abortion, contraception, and euthanasia as being indicative of a "culture of death" in Evangelium Vitae. His call for a culture of life sounds very positive, but when such policies lead to the Repugnant Conclusion, we must question their logic. Would God prefer a world made up of one hundred billion sad people or ten billion happy ones?

There is a parallel here with the Church's policy on assisted dying. Just as the Church's "pro-life" policy on euthanasia condemns people to carry on living in pain and 
indignity when they want to die, its policies on sex and abstinence would ultimately lead to lives that are degraded in quality because of the sheer number of other lives. A truly pro-life policy would be one that allowed individuals to end their lives if they decide that it is no longer worth living, just as such a policy would recognize that there must be an upper limit to the size of the population in order to avoid a world like Earth-C or Z. In both cases, the Church regards the "pro-life" position as being an imperative to maximize quantity, rather than quality of life - the very problem posed by the Repugnant Conclusion.

\section{Potential Objections}

It might be argued that the picture I have sketched is very uncharitable to Catholicism. As mentioned in the introduction, many liberal Catholics nowadays do not adhere to the strictures of the Vatican regarding sexual orientation and reproduction. Furthermore, the current Pope has given several signs that he is rather more liberal in his interpretation of scripture, adopting a more conciliatory approach to people who are gay and women who have had abortions (although the latter group are only to receive "mercy" for a period of one year).

Nonetheless, the Pope still maintains that homosexuality and abortion are both sins, most senior figures in the church are less liberal than he is, and no indication has been given that doctrinal change is on the agenda. More importantly, Earth-C is a thought experiment designed to illustrate the consequences of global rule according to classical Church doctrine. Liberal Catholics do not and cannot exist on Earth-C, as there is no scope for disagreement without risking a visit from the Inquisition. It might be argued that the Church (in our world) is itself much more liberal than it was two hundred years ago, but it is difficult to know how liberal it would remain if it enjoyed absolute power and did not have to exist alongside other religions and atheists in a pluralistic society. Indeed, it is arguable that the closest we have come in our history to Earth-C was during the height of the Church's power, when heretics were murdered and millions were oppressed. But that was hundreds of years ago before the Industrial Revolution, when population growth was not such a problem and man-made climate change was not an issue; if we all woke up tomorrow to find ourselves living on Earth-C, we might not be so sanguine about the Church's supposed liberality and the consequences for life on our planet. If anything, I have erred on the side of being too kind to the Church in this paper by conceding that homosexuality would not be outlawed on Earth-C (as it was in the past on our Earth) and that patients would be permitted to refuse extraordinary treatment, as is sometimes not the case in very Catholic countries such as Italy.

Another objection might be that I have unfairly singled out Catholicism in this paper, rather than focusing on the potential ethical effects of global implementation of Islamic, Judaic, Protestant, or Buddhist doctrine. It is certainly true that some applications of sharia law (for example) raise significant human rights issues, and all religions have potential ethical problems. But the Catholic Church is unique in that its policies on bioethical issues are core to the Church's identity and are closely identified with the Church itself. Furthermore, extreme interpretations of Islam are just that, while the doctrines discussed in this paper are core and not open to interpretation (despite the fact that many liberal Catholics disregard them). Perhaps more importantly, Catholic figures play a major role in opposing legislation that would permit assisted suicide, abortion, and equal rights for those who are gay, which is not generally true of the other religions. The influence of the Catholic Church is strong, even in relatively secular countries such as the United Kingdom and the United States, but in some heavily Catholic countries the Church has been successful in opposing abortion in all circumstances (Ireland until 2013) and in opposing letting patients die by removing life support (Italy). In Venezuela, women who have an abortion can be jailed for two years, and Pope Benedict XVI himself urged the president not to weaken abortion law (Fisher 2006).

\section{Conclusion}

The example of Earth-C suggests that implementation of Catholic doctrine on a global scale would ultimately lead to human rights violations on a massive scale, an exponential increase in global population and global warming, and a consequent decrease in the quality of life for most people. If you sought to engineer Z, Parfit's world where there are tens of billions more people whose lives are barely worth living, the best route might well be to adopt Catholic doctrine as your guide to policy. Fortunately, most countries on our planet do not adhere to the pro-quantity, anti-quality "pro-life" doctrines of the Catholic Church, and we remain a long way from the world of the Repugnant Conclusion. 
Box 1. Catholic sources

"Direct abortion, that is to say, abortion willed either as an end or a means, is gravely contrary to the moral law" (Sacred Congregation for the Doctrine of the Faith 2009, $\llbracket 3$ ).

"Thus the innate language that expresses the total reciprocal selfgiving of husband and wife is overlaid, through contraception, by an objectively contradictory language, namely, that of not giving oneself totally to the other. This leads not only to a positive refusal to be open to life but also to a falsification of the inner truth of conjugal love" (Pope John Paul II 1981, $\$ 4$ under "In an Integral Vision of the Human Person and of His or Her Vocation").

"For it is a question of the violation of the divine law, an offense against the dignity of the human person, a crime against life, and an attack on humanity" (Sacred Congregation for the Doctrine of the Faith 1980, under "II. Euthanasia”).

\section{References}

Fisher, I. Pope takes on Chavez. 2006. The New York Times, May 12. http://www.nytimes.com/2006/05/12/world/americas/ 12briefs-brief-001.html. Accessed December 7, 2015.
Parfit, D. 1987. Reasons and persons. Oxford: Oxford University Press.

Parfit, D. 1986. Overpopulation and the quality of life. In Applied Ethics, edited by P. Singer, 7-22. New York: Oxford University Press.

Pope John Paul II. 1981. Familiaris consortio. http://www.vatican. va/holy_father/john_paul_ii/apost_exhortations/documents/ hf_jp-ii_exh_19811122_familiaris-consortio_en.html. Accessed December 7, 2015.

Pope John Paul II. 1995. Evangelium vitae. http://w2.vatican.va/ content/john-paul-ii/en/encyclicals/documents/hf_jp-ii_enc 25031995_evangelium-vitae.html. Accessed December $\overline{7}$, 2015.

Sacred Congregation for the Doctrine of the Faith. 1980. Declaration on euthanasia. http://www.vatican.va/roman curia/congregations/cfaith/documents/rc con_cfaith_doc19800505 euthanasia en.html. Accessed December 7, 2015.

Sacred Congregation for the Doctrine of the Faith. 2009. Clarification on procured abortion. http://www.vatican.va/ roman_curia/congregations/cfaith/documents/rc_con cfaith_doc_20090711_aborto-procurato_en.html. Accessed December 7, 2015.

Underhill, K., P. Montgomery, and D. Operario. 2007. Sexual abstinence only programmes to prevent HIV infection in high income countries: Systematic review. British Medical Journal 335: 248. doi:10.1136/bmj.39245.446586.BE. 